\title{
The Influence of Earning Per Share, Price Earnings Ratio, and Price to Book Value toward Price of Stok of Coal Mining Companies Listed in the Indonesia Stock Exchange During 2014-2018
}

\author{
Rr. Jean Brebeuf Iryani Andamari \\ Sanata Dharma University Yogyakarta \\ brebeufjean@gmail.com \\ Caecilia Wahyu E. Rahayu \\ Sanata Dharma University Yogyakarta \\ caecilia50@gmail.com \\ Ima Kristina Yulita \\ Sanata Dharma University Yogyakarta \\ yulitaimakristina@gmail.com
}

\begin{abstract}
Company's financial performance is a factor considered by investors in investing. This study aims to determine the effect of Earning per Share (EPS), Price Earnings Ratio (PER), and Price to Book Value (PBV) on stock price. Eight coal mining companies listed in the Indonesia Stock Exchange (IDX) in 2014-2018 were taken for the samples of this research using purposive sampling technique. Multiple linear regression was used to analyze the data. The results show that (1) EPS, PER, and PBV simultaneously have a significant effect on stock price with a significance value of 0.000 ; (2) EPS and PBV partially have a significant effect on stock price with a significance value of 0.000 and 0.006 respectively. EPS, PER, and PBV can explain variation of the stock price of the coal companies listed in the IDX in 2014-2018 as much as $88.5 \%$. The results of this study is expected to provide recommendations for investors in choosing stocks of coal mining company with good performance based on EPS and PBV ratios.
\end{abstract}

Keywords: coal industry, EPS, PER, PBV, stock price.

\section{INTRODUCTION}

Generally, an investment is conducted by postponing current consumption and allocating it on productive assets for particular periods (Hartono, 2017:5). Such activity can be either in money market or capital market and can be either fixed tangible asset or financial asset. According to Halim (2018:3), capital market connects those who offer and those who need 
long-term funds in terms of bond, equity (stocks), mutual funds, derivative instruments, or other instruments. Thus, investors can transact securities such as stocks, bonds, and mutual funds in a capital market (Tandelilin, 2017:25). Stock is one of preferable investment instruments in capital market because it can give interesting benefits for investors.

There are many companies that can be the alternatives for investor to invest their money in the capital market. One of them are those operating in mining sector and in particularly coal mining. Companies in this industry are interesting since Indonesia is one of the biggest coal producers and exporters in the world. According to International Energy Agency Coal Information (2020), Indonesia is the fourth biggest coal producers in the world and Indonesia coal is in high demand in the global market because the coal is considerably environmentally friendly and thus is safe to be used as fuel power plant (http://republika.co.id, 2020). Table 1 presents data of production, export, and domestic usage of coal in 2015-2019.

Based on Table 1, coal production increased from 461.29 million ton in 2015 to 616.16 million ton in 2019. Similarly, the domestic usage of coal was also increasing during the same period. Even though the export decreased from 2015 to 2017, it increased in 2018 and 2019. Proportion of raw coal to production was approximately $60 \%$ - 80\% annually during 2015-2019 (https://republika.co.id, 2020). Main destination countries for coal export are China, India, Japan, and South Korea.

Table 1. Production, Export, and Domestic Usage of Coal in 2015-2019 (million ton)

\begin{tabular}{cccc}
\hline Year & Production & Export & Domestic \\
\hline 2019 & 616.16 & 454.50 & 138.42 \\
2018 & 557.77 & 356.39 & 155.08 \\
2017 & 461.36 & 286.94 & 97.03 \\
2016 & 456.17 & 331.37 & 91 \\
2015 & 461.29 & 365.75 & 86
\end{tabular}

Source: Directorate of General of Mineral and Coal, Ministry of ESDM (2020) 
In 2020, the Indonesian government decided to reduce export of raw coal and use it to build the downstream in the country. The coal will be transformed into commodities with value added 2-3 time higher such as methanol that can be a mixture for biodiesel (Fatty Acid Methyl Esters/ FAME) and Dimethyl Ether (DME) that can be used as substitution of LPG (https://www.republika.com, 2021). This policy is supported by PT PLN which has been using coal for the fuel of steam plant (PLTU) (https://www.antaranews.com, 2019).

Considering production growth, export, and usage of coal in the country that are increasing, stocks of coal mining companies become an interesting alternative for investing. Under such prospective condition, investors expect that the prospect of coal mining companies will also be potential. Thus, they must know the company's financial performance before investing to predict their prospect in the future.

Financial performance of a company can be seen from its published financial reports. Financial report indicates financial condition of the company at the current time or a particular period (Kasmir, 2014:7). It aims at providing information beneficial for investors and creditors in making investment and credit decisions (Hery, 2015:4). Financial report can be analyzed by comparing one account to another available in the report for calculating financial ratios. The ratios can describe good and bad of financial condition of the company (Sujarweni, 2017:59).

There are several financial ratios that can be used to evaluate a company's financial capability. However, only three ratios usually selected to describe financial performance of coal mining companies: profitability ratio and market value ratios. These ratios are considerably more interesting, simpler, and easier for investors to understand it. Profitability ratio is a ratio to measure the success of the management in providing profit for regular stockholders (Hery, 2015). The higher the profitability ratio, the better the performance of the company. Earnings per Share (EPS) is profitability ratio that indicates ability of the company 
in generating profit for each stock. It indicates relationship between total net profit and proportion of the stockholders' ownership in the company. Higher ratio indicate better financial condition of the company since it shows higher profit distributed to the stockholders, and thus can attract more investors to buy its stocks which then leads to higher price of the stocks. However, some research on the influence of EPS on stock price end with controversial result (Lestari, 2012; Mahfudz and Dwinurcahyo, 2016; Khairudin and Wandita, 2017; Apsara, 2017; Nurriqli and Sofyan, 2018; Agustina, 2018; Hing et al., 2020; Prabu et al., 2020; Abdullah et al., 2016; Khairani, 2016).

Market value ratio relates to company's stock price, cash flow, and book value of a stock. This ratio gives indication for management about investors' view on risks and prospect of the company in the future (Brigham \& Houston, 2016). PER (Price Earnings Ratio) and PBV (Price to Book Value) are the representation of market value ratio. PER is a ratio between stock price and profit of the company. A stock with lower PER is more interesting for investors because profit per stock is relatively higher than the price of the stock (Hery, 2015:169). Some research show different results (Lestari, 2012; Zuliarni, 2012; Dalimunthe, 2015; Mahfudz and Dwinurcahyo, 2016; Abdullah et al., 2016, Prabu et al., 2020). According to Hery (2015:170), PBV is a ratio indicating proportion of market price of a stock to its book value. This ration is used to measure if stock price is either overvalued (stock price is expensive) or undervalued (stock price is cheap). Lower PBV indicates declining quality and fundamental performance of the issuer. On the other side, higher PBV reflects higher evaluation of investors on company performance, then this will affect demand of the stock that will leverage its price. Some research support the influence of PBV on stock price (Lestari, 2012; Mahfudz and Dwinurcahyo, 2016; Khairudin and Wandita, 2017; Apsara, 2017; Nurriqli et al., 2018; Hing et al., 2020). 
The goal of this research is to understand simultaneous and partial effect of EPS, PER, and PBV on price stocks of companies in coal mining industry.

\section{LITERATURE REVIEW}

\section{Stock Price}

According to Samsul (2015:197), stock price is the price set in the market that is influenced by the law of supply and demand. Wira (2011:7) stated that stock price reflects the company's performance. The price that is too low or too high distresses liquidity of the stock. High price stock is less transacted, while the low price one can delisted (kicked off the market).

Fahmi (2015:329) noted factors affecting stock price are as follow:

a. Micro and macro conditions

b. Company's policy for expansion by for example opening branch offices and supporting branch offices in either the country or abroad.

c. Sudden replacement of the director

d. The company's director or commissioner who involved in criminal offense that has been listed in the court

e. Company's performance that is continuously declining

f. Systematical risks, which reflect a form of risk that is complete and has caused the company involved

g. Market psychology, which is a process or change in condition of the market caused by traders' behavior.

\section{Fundamental Analysis}

According to Wira (2011), fundamental analysis is a technique for calculating factors such as company performance, competition analysis, industry analysis, economic analysis, and 
macro-micro market. Srinivasan (2013) also stated that understanding on the influence of fundamental variables on stock price will help investors in making profitable investment decision.

Financial ratios are ratios calculated using financial reports which are the measurements for company financial condition and performance (Hery, 2015:161). There are three ratios to be the focus:

Earnings per Share (EPS)

As stated by Tandelilin (2017:376), EPS is company's profit that is ready to be distributed for the stockholders. According to Sukamulja (2019:103), EPS measures net profit in each stock issued by the company. EPS is ratio used by the investors in evaluating profitability of a company. EPS is calculated using the following formula:

$$
E P S=\frac{\text { nett profit }}{\text { number of stocks issued }}
$$

\section{Price Earnings Ratio (PER)}

According to Hery (2015: 169), PER is ratio between price of a stock and its profit. Through this ratio, price of stock of an issuer is compared to net profit resulted by the issuer in a year. Using PER, a potential investor can know if price of a stock is reasonable (in real) according to current condition and not to the estimation of future condition. Tandelilin (2017:321) stated that PER depicts ratio price of stock and earning contained in the price of the stock. PER indicates rupiah that must be paid to investors to receive one rupiah of earning from the company. PER is a measurement of relative price of a company's stock. According to Sukamulja (2019:104), price to earnings ratio describes valuation of price of a stock compared to its profit. The higher the value of PER, the more expensive of a stock and vice versa. PER also reflects growth of the stock. If PER is high, not only the price of the stock is more expensive but its growth is also higher. The formula for calculating PER is as follows: 


$$
P E R=\frac{\text { Price of a stock }}{\text { Profit of a stock }}
$$

Price to Book Value (PBV)

According to Sukamulja (2019:105), market to book ratio/price to book value is an important ratio in calculating value of a company. This ratio describes valuation of a stock compared to book value of the stock. The higher the value of PBV, the more expensive is the stock and vice versa. Higher price of a stock indicates higher valuation of investor on the company's performance. PBV that is higher than 1 reflects market value of the company is higher than its book value stated in its financial report. The formula for calculating PBV:

$$
\begin{aligned}
\text { Book Value } & =\frac{\text { Number of Equity }}{\text { Number of stocks issued }} \\
\text { PBV } & =\frac{\text { Price of a stock }}{\text { Book value of a stock }}
\end{aligned}
$$

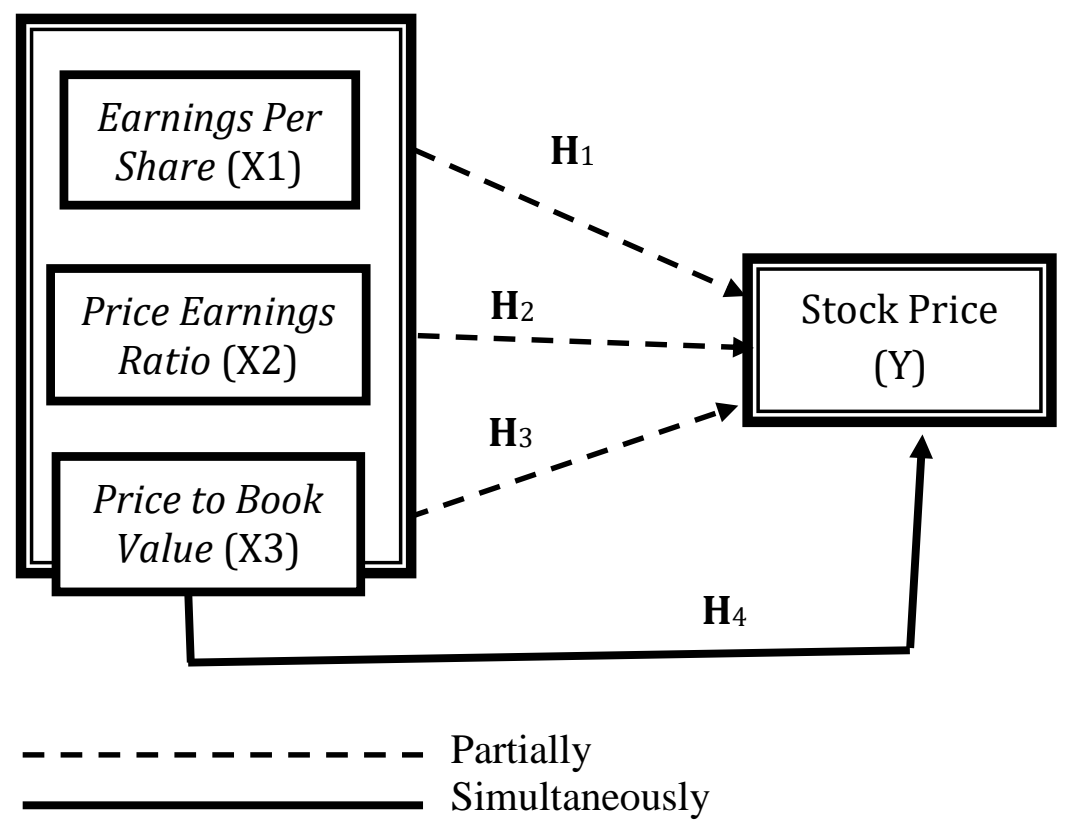

Figure 1. Research Framework 


\section{Hypothesis Building}

\section{Influence of Earnings per Share (EPS) toward Price of Stock}

Earnings per Share (EPS) measures how much net profit containing in per share issued. EPS is a ratio used by investor to calculate profitability of a company (Sukamulja, 2019:103). This ratio indicates relationship between net profit and share of ownership of stockholders in the company. The bigger the ratio is better since it influences price of the share to increase. This is supported by the research of Lestari (2012), Mahfudz and Dwinurcahyo (2016), Khairudin and Wandita (2017), Apsara (2017), Nurriqli and Sofyan (2018), Agustina (2018), Hing (2020), and Prabu et al. (2020, which resulted in EPS influences price of stock. Based on this argument, the hypothesis is thus as follows:

$$
\mathrm{H}_{1}=\text { Earnings per Share influences price of stock }
$$

\section{Influence of Price Earnings Ratio (PER) toward Price of Stock}

According to Hery (2015:169), PER is a ratio between market price per share and profit per share. Through this ratio, price of stock of an issuer is compared to yearly net profit resulted by the issuer. By knowing the PER, potential investors can know if price of a stock is reasonable or not (actually) according to the current condition instead of estimation of the future. This ratio is important since it gives information on reasonable value of a company. Stock with low PER is more interesting for investors to buy it because it indicates higher profit compared to its price and indicates price of stock that is relatively cheap (undervalued) so it is suitable for long term investment. PER also indicates growth of the stock. High PER reflects the company's price of stock and growth that are high (Sukamulja, 2019: 104). The research of Zuliarni (2012), Dalimunthe (2015), Mahfudz and Dwinurcahyo (2016), and Prabu et al. (2020) support that PER affects price of stock. Based on this explanation, the hypothesis is as follows:

$$
\mathrm{H}_{2}=\text { Price Earnings Ratio influences price of stock }
$$




\section{Influence of Price to Book Value (PBV) toward Price of Stock}

Price to book value is an important ratio in calculating value of a company. According to Hery (2015:170), PBV is a ratio indicating valuation of price per share compared to book value per share. Higher PBV represents higher price per share, and vice versa. The more expensive of a stock reflects higher valuation of investors on company performance. Value of PBV that is more than 1 indicates market value of the company is higher than its book value recorded in its financial report (Sukamulja, 2019:105). This is supported by the research of Lestari (2012), Mahfudz and Dwinurcahyo (2016), Khairudin and Wandita (2017), Apsara (2017), Nurriqli and Sofyan (2018), and Hing et al. (2020) who stated that PBV influences price of stock. Referring to this, the hypothesis is thus as follows:

$$
\mathrm{H}_{3}=\text { Price to Book Value influences price of stock }
$$

Influence of Earning Per Share (EPS), Price Earnings Ratio (PER), and Price to Book Value (PBV) toward Price of Stock

The higher the EPS, the higher the price of stock and vice versa. The higher the PER, the more expensive is the price of stock and vice versa. The higher the PBV, the higher the price of stock and vice versa. These show that price of stock in coal sector can be affected by EPS, PER, and PBV since the increase in the three ratios can increase the price of company's stock. The research of Maffudz and Dwinurcahyo (2016), found that Earning per Share (EPS), Price Earnings Ratio (PER), and Price to Book Value (PBV) simultaneously influence price of stock. Referring to this, the hypothesis is thus as follows:

$$
\begin{gathered}
\mathrm{H}_{4}=\text { Earnings per Share, Price Earnings Ratio, and Price to Book Value } \\
\text { simultaneously influence price of stock }
\end{gathered}
$$

\section{METHODS}

This is an associative research with the independent variables are Earning Per Share (EPS), Price Earnings Ratio (PER), Price to Book Value (PBV) and the dependent variable is 
price of stock at the end of company year in coal industry. According to Samsul (2015:197), price of stock is the price created in the market in which the amount is influenced by the law of demand and supply.

\section{Population and Sample}

Population of this research is 26 coal mining companies listing in the Indonesia Stock Exchange in the period of 2014-2018. Purposive sampling was applied using particular considerations in order to get data that are representative. The considerations for selecting sample companies are (1) companies operating in coal industry that are listed in the Indonesia Stock Exchange during the period of 2014-2018; (2) companies have complete financial reports and record positive profit from 2014 to 2018; (3) companies have complete data about the moving of price of stock during the period of 2014-2018; (4) companies are in the main board index and development board in the record of the Indonesia Stock Exchange; (5) companies record positive profit based on the financial report issued in the period of 2014-2018. There were 8 companies that meet the criteria.

Table 2. The Sample Companies

\begin{tabular}{lll}
\hline NO & KODE & EMITEN \\
\hline $\mathbf{1 .}$ & ADRO & Adaro Energy Tbk \\
$\mathbf{2 .}$ & BSSR & Baramulti Suksesarana Tbk \\
3. & ITMG & Indo Tambangraya Megah Tbk \\
$\mathbf{4 .}$ & KKGI & Resource Alam Indonesia Tbk \\
$\mathbf{5 .}$ & MBAP & Mitrabara Adiperdana Tbk \\
$\mathbf{6 .}$ & MYOH & Samindo Resource Tbk \\
7. & PTBA & Bukit Asam Tbk \\
8. & TOBA & Toba Bara Sejahtera Tbk \\
\hline
\end{tabular}

Source: www.idx.co.id

\section{Source of Data}

Data used in the research is secondary gathered from yearly financial report of the sampled companies. Data was downloaded from the company website, www.idx.co.id, and www.bps.go.id. 


\section{Data Collecting Method}

Method for collecting data is documentation. This resulted in panel data, which is the combination of cross section and time series data. Cross section data was used to collect data of EPS, PER, and PBV of the companies. Meanwhile, time series data was to get data of EPS, PER, and PBV in the year of 2014-2018.

\section{Data Analysis Method}

\section{Classical Assumption Tests}

The tests were aimed to give certainty that the regression equation resulted gives accuracy for estimation, is unbiased, and is consistent. The tests comprise of normality, multicollinearity, heteroscedasticity, and autocorrelation.

\section{Multiple Linear Regression Analysis}

According to Silalahi (2018:272), Multiple Regression Analysis is regression analysis that is used to evaluate or measure prediction strength between two or more independent variables toward a dependent variable. The regression equation is as follows: $\quad Y=a+$ $\mathrm{b}_{1} \mathrm{X}_{1}+\mathrm{b}_{2} \mathrm{X}_{2}+\mathrm{b}_{3} \mathrm{X}_{3}+e$

in which, $\mathrm{Y}=$ Price of stock; $\mathrm{a}=$ Constanta; $\mathrm{b}_{1} \mathrm{~b}_{2} \mathrm{~b}_{3}=$ Coefficients; $\mathrm{X}_{1}=\mathrm{EPS} ; \mathrm{X}_{2}=$ PER; $\mathrm{X}_{3}=$ PBV; $e=$ error term.

\section{Test of Hypotheses}

\section{F Test (simultaneously)}

F test was used to know if all independent variables in the regression model influence simultaneously the dependent variable under the significance of $\alpha=0.05$. The decision to reject $\mathrm{H}_{0}$ or to accept $\mathrm{H}_{\mathrm{A}}$ if probability $(\mathrm{sig}) \leq \alpha$, meaning Earning Per Share, Price Earnings Ratio and Price to Book Value simultaneously affect significantly price of stock. Otherwise, $\mathrm{H}_{0}$ is 
accepted or $\mathrm{H}_{\mathrm{A}}$ is rejected if probability (sig) $>\alpha$, meaning Earning Per Share, Price Earnings

Ratio and Price to Book simultaneously do not affect significantly price of stock.

t test (partially)

$\mathrm{t}$ test was conducted using SPSS by comparing level of significance (sig) of each independent variable to significance of $\alpha=0.05$. the decision to reject $\mathrm{H}_{0}$ or to accept $\mathrm{H}_{\mathrm{A}}$ if probability $(\mathrm{sig}) \leq \alpha$, meaning Earning Per Share, Price Earnings Ratio and Price to Book Value partially affect significantly price of stock. On the other side, $\mathrm{H}_{0}$ is accepted or $\mathrm{H}_{\mathrm{A}}$ is rejected if probability (sig) $>\alpha$, meaning Earning Per Share, Price Earnings Ratio and Price to Book Value partially do not affect significantly price of stock.

\section{Coefficient of Determination $\left(R^{2}\right)$}

According to Ghozali (2016:98), coefficient of determination is to measure the ability of the model in explaining variation of changes of dependent variable. Its value ranges from 0 to 1 . The smaller the value of $\mathrm{R}^{2}$ means ability of the independent variables in explaining variation of dependent variable is limited. In particularly, it is to know how big the effect of Earning per Share, Price Earnings Ratio, and Price to Book Value to changes in price of stock of companies in coal industry. The research uses Adjusted R Square for this purpose.

\section{RESULT AND DISCUSSION}

Table 3 presents description of the variables. EPS indicates profit per stock issued. The lowest and the highest value of EPS are respectively Rp1.35 and Rp3,259.51 or Rp502.89 on average. The sample companies have average PER of 16.38 , which indicates that average price of the stock is 16.38 times of the average net income per stock a year. The lowest and highest PER are 0.84 and 261.47 respectively. In terms of PBV, with the lowest and highest values are respectively 0.08 and 3.9, its average value is 1.46 which means the average price of a stock is 
1.46 times of the average book value. Stock price gained from the closing price at the end year of each company results in the cheapest of Rp84, the most expensive of Rp20,700 and the average of Rp3,397.95.

Table 3. Statistical Description of the Variables

\begin{tabular}{lccccc}
\hline & $\mathrm{N}$ & Minimum & Maximum & Rata-rata & $\begin{array}{c}\text { Standard } \\
\text { deviation }\end{array}$ \\
\hline EPS (Rp/stock) & 40 & 1.35 & $3,259.51$ & 502.89 & 740.45 \\
PER & 40 & 0.84 & 261.47 & 16.38 & 44.92 \\
PBV & 40 & 0.08 & 3.91 & 1.46 & 0.93 \\
Sttock price (Rp) & 40 & 84 & 20,700 & $3,397.95$ & $5,487.14$ \\
\hline
\end{tabular}

\section{The Results of Classical Assumption Tests}

Normality test resulted in Asymptotic Significance on One-Sample KolmogrovSmirnov is 0.152 (Table 4), which is higher than 0.05 and thus it is concluded that the residuals are distributed normally.

Table 4. One-Sample Kolmogorov-Smirnov Test of Normality

\begin{tabular}{llr}
\hline & & Unstandardized Residual \\
\hline $\mathrm{N}$ & & 40 \\
Normal Parameters $^{\mathrm{a}}$ & Mean & .0000000 \\
& Std. Deviation & $1.79056492 \mathrm{E} 3$ \\
Most Extreme & Absolute & .179 \\
Differences & Positive & .179 \\
& Negative & -.095 \\
Kolmogorov-Smirnov Z & & 1.135 \\
Asymp. Sig. (2-tailed) & & .152 \\
\hline
\end{tabular}

Table 5 presents the result of multicollinearity test, which resulted VIF (Variance Inflation Factor) of all independent variables are less than 10. It thus can be concluded that the regression model does not experience multicollinearity. 
Table 5. Multicollinearity Test

\begin{tabular}{cccccc}
\hline & & \multicolumn{2}{c}{ Unstandardized Coefficients } & \multicolumn{2}{c}{ Collinearity Statistics } \\
\cline { 3 - 6 } & Model & B & Std. Error & Tolerance & VIF \\
\hline 1 & (Constant) & -1460.012 & 576.784 & & \\
& EPS & 6.793 & .411 & .960 & 1.042 \\
& PER & 1.795 & 6.937 & .920 & 1.087 \\
& PBV & 966.512 & 332.263 & .932 & 1.073 \\
\hline
\end{tabular}

The result of Park Gleyser test presented in table 6 shows that significance value of the three variables is equal and higher than 0.05 and thus it can be concluded that regression model does not experience heteroscedasticity.

Table 6. Heteroscedasticity Test - Park Gleyser

\begin{tabular}{llrrr}
\hline & & \multicolumn{2}{c}{ Unstandardized Coefficients } & \\
\cline { 2 - 4 } \multicolumn{1}{l}{ Model } & \multicolumn{1}{c}{ B } & Std. Error & \multicolumn{1}{c}{ Sig. } \\
\hline 1 & (Constant) & 674.096 & 403.298 & .103 \\
& EPS & .553 & .288 & .062 \\
& PER & -2.889 & 4.851 & .555 \\
& PBV & 181.689 & 232.325 & .439 \\
\hline
\end{tabular}

Referring to table 7, Durbin-Watson test resulted in the value of 1.730 . With 3 independent variables $(\mathrm{k}=3)$ and number of observation $\mathrm{n}=40, \mathrm{dL}=1.3384$ and $\mathrm{dU}=1.6589$ since the value of Durbin-Watson is in the range of dU and $4-\mathrm{dU}$, it can be concluded that there is no autocorrelation.

Table 7. Autocorrelation Test

\begin{tabular}{lccrr}
\hline \multicolumn{5}{c}{ Model Summary $^{\mathbf{b}}$} \\
\hline Model & $\mathrm{R}$ & R Square & Adjusted R Square & Durbin-Watson \\
\hline 1 & $.945^{\mathrm{a}}$ & .894 & .885 & 1.730 \\
\hline a. Predictors: (Constant), PBV, EPS, PER & & \\
b. Dependent Variable: Price of Stock
\end{tabular}

\section{The Result of Multiple Linear Regression Analysis}

As presented in table 8, regression resulted in the following equation:

$$
Y=-1,460.012+6.793 X_{1}+1.795 X_{2}+966.512 X_{3}
$$


Table 8. Result of Multiple Linear Regression Analysis

\begin{tabular}{cccccc}
\hline & & \multicolumn{2}{c}{$\begin{array}{c}\text { Unstandardized } \\
\text { Coefficients }\end{array}$} & t & Sig. \\
\cline { 3 - 6 } & Model & B & Std. Error & & \\
\hline 1 & (Constant) & -1460.012 & 576.784 & -2.531 & .016 \\
& EPS & 6.793 & .411 & 16.512 & .000 \\
& PER & 1.795 & 6.937 & .259 & .797 \\
& PBV & 966.512 & 332.263 & 2.909 & .006 \\
\hline
\end{tabular}

\section{Partial Hypothesis Test ( $t$ test)}

Probability (sig) Earning per Share is 0.000 that is lower than $\alpha(0.000<0.05)$ and thus $\mathrm{H}_{1}$ is accepted. In other words, Earning per Share partially influences significantly price of stock.

Probability (sig) Price Earnings Ratio is 0.797 that is bigger than $\alpha(0.797>0.05)$ and thus $\mathrm{H}_{2}$ is rejected, meaning that Price Earnings Ratio partially does not influence significantly price of stock.

Probability (sig) Price to Book Value is 0.006 that is lower than $\alpha(0.006<0.05)$ and thus $\mathrm{H}_{3}$ is accepted, meaning that Price to Book Value partially influences significantly price of stock.

\section{Simultaneous Hypothesis Test (F test)}

Referring to table 9, Probability (sig) of Earning Per Share, Price Earnings Ratio, and Price to Book Value together is 0.000 that is lower than $\alpha(0.000<0.05)$, and thus $\mathrm{H}_{0}$ is rejected. This means that the variables simultaneously influence significantly price of stock.

Table 9. ANOVA Test

\begin{tabular}{ccccc}
\hline & Model & Sum of Squares & F & Sig. \\
\hline 1 & Regression & $1.049 \mathrm{E} 9$ & 100.692 & $.000^{\mathrm{a}}$ \\
& Residual & $1.250 \mathrm{E} 8$ & & \\
& Total & $1.174 \mathrm{E} 9$ & & \\
\hline
\end{tabular}




\section{Coefficient of Determination}

Table 10 show the value of Adjusted $\mathrm{R}^{2}$ that is 0.885 . This means that $88.5 \%$ variations in changes of price of stock in coal industry is affected by components of EPS, PER, and PBV. The rest of $11.5 \%$ is affected by other variables outside those under this research.

Table 10. The Result of Coefficient of Determination

\begin{tabular}{llrrrr} 
Model & R & R Square & $\begin{array}{c}\text { Adjusted R } \\
\text { Square }\end{array}$ & $\begin{array}{c}\text { Std. Error of the } \\
\text { Estimate }\end{array}$ \\
\hline 1 & $.945^{\mathrm{a}}$ & .894 & .885 & 1863.679 \\
\hline
\end{tabular}

\section{Discussion}

Earnings per Share and Price of Stock

Almumani (2014), Maholtra \& Tandon (2013), and Sharma (2011) mntioned that EPS is one of the factors determining price of the stock. The result of this research indicates that EPS affect significantly price of stock. Referring to Hery (2015:169), EPS is ratio for measuring the success of the management in providing profit for common stockholders. Thus, the higher the EPS indicates the bigger the profit that can be gained by the stockholders. High profit encourages investors to buy the company's stock that results in the increase of stock price. This result is in line with that of Lestari (2012), Mahfudz and Dwinurcahyo (2016), Khairudin (2017), Apsara (2017), Nurriqli et al. (2018), Agustina (2018), Hing (2020), and Prabu et al. (2020) who also found that effect of EPS on stock price.

\section{Price Earning to Ratio and Price of Stock}

Referring to the counter movement, PER tends to move in the opposite direction from earnings. Thus, if earnings deviate from the level considered as normal by the market, PER will adjusts themselves to the level that make the market price is not changed (Block, 1995). The movement of PER is also influenced by the investors' sentiment in terms of trade volume and price volatility (Jitmaneeroj, 2017). The result shows that Price Earning to Ratio (PER) does not influent significantly price of stock. The reason is that higher PER of the coal mining 
companies was not accompanied by growth of the company while the price of its stock was becoming more expensive. This indicates low performance of the companies during the periods that made the investors doubted the company's growth and thus lowered their trust to the companies' stocks. Lower trust of the investor affected demand of the stock and then the price of the stock. Moreover, PER might be incorrect for several companies in the industry since they produced relatively small profit and thus higher PER was not because of higher price of the stock but rather small profit and thus it did not affect significantly this sector. This result does not support that of Zuliarni (2012), Dalimunthe (2015), Mahfudz and Dwinurcahyo (2016), and Prabu et al. (2020) who concluded that PER affect significantly price of stock. However, the result is in line with that of Abdullah et al. (2016) and Lestari (2012) concluding that PER does not affect stock price.

\section{Price to Book Value and Price of Stock}

PBV describes the unity factors of internal and external price, completes the company's market cycle and analysis (Block, 1995). Chan et al. (1995) shows that company size and PBV affect return of the stock. This is apparent that small size company with low PBV is generally riskier and thus investors ask for higher return.

The result shows that Price to Book Value (PBV) affects significantly price of stock. The effect indicates success of the management performance in managing resources that was reflected in end-year price of stock and was seen from value of equity in their corporate acts. Higher PBV increases expectation and trust of the investors to gain higher profit. Higher trust will consequently increase interests of the investors to invest on the company and in turn it increases demand on the stock and as a result the price of the stock will also increase since it can possibly give better prospect in the future. This result is supported by the research of Lestari (2012), Mahfudz and Dwinurcahyo (2016), Khairudin and Wandita (2017), Apsara (2017), 
Nurriqli and Sofyan (2018), and Hing et al. (2020) who found that PBV affects significantly price of stock.

Earnings per Share (EPS), Price Earnings Ratio (PER), and Price to Book Value (PBV) and Price of Stock

The result indicates that EPS, PER, and PBV simultaneously affect significantly price of stock. It is obvious from the test of ANOVA which resulted probability with significance value (sig) of 0.000 which is smaller than $\alpha(0.000<0.05)$. This result is in line with that of Mahfudz and Dwinurcahyo (2016). This means fundamental factor and systematical risk determine fluctuation of the company's stock price. Adjusted $\mathrm{R}^{2}$ of 0.885 means that variation of changes in price of stocks of those in coal industry listed in the Indonesia Stock Exchange during 2014-2018 was $88.5 \%$ affected strongly by EPS, PER, and PBV. Meanwhile, the rest of $11.5 \%$ was affected by other variables not covered by this research.

\section{CONCLUSIONS AND POLICY IMPLICATIONS}

Based on the data analysis, it can be concluded that (1) EPS, PER, and PBV) simultaneously affect price of stock of the coal mining companies listed in the Indonesia Stock Exchange in the period of 2014-2018; (2) EPS partially affects significantly price of stock of the coal mining companies listed in the Indonesia Stock Exchange in the period of 2014-2018; (3) PER partially does not affects significantly price of stock of the coal mining companies listed in the Indonesia Stock Exchange in the period of 2014-2018; (4) PBV partially affects significantly price of stock of the coal mining companies listed in the Indonesia Stock Exchange in the period of 2014-2018.

Relevant suggestions that can be provided are: (1) investors or potential investors need to pay attention on fundamental factors such as financial ratios and other external factors of the 
companies in coal industry that will be their investment portfolios. (2) Companies operating in coal mining industry should maintain and increase their abilities in generating net profit indicating in EPS and increase equity in managing resources indicating in PBV. (3) Future researchers can add the most current periods in the research and add financial ratios and other analysis to get more accurate information.

\section{REFERENCES}

Abdullah, H., Soedjatmiko, Hartati, A. (2016). Pengaruh EPS, DER, PER, ROA dan ROE Terhadap Harga Saham Pada Perusahaan Tambang yang Terdaftar di BEI untuk Periode 2011-2013. Dinamika Ekonomi Jurnal Ekonomi dan Bisnis. 9 (1), 1-20.

Almumani, M. A. (2014). Determinants of Equity Share Prices of the Listed Banks in Amman Stock Exchange: Quantitative Approach. International Journal of Business and Social Science. 5(1), 91-104.

Apsara, R. H. (2017). Analisis Pengaruh Crude Oil Price, Earning Per Share, Prive Book Value, Return On Asset dan Debt to Equity Ratio terhadap Harga Saham. Perusahaaan Subsektor Batubara yang Terdaftar di Bursa Efek Indonesia Periode 2012-2016. Skripsi. Fakultas Ekonomika dan Bisnis Universitas Diponegoro Semarang.

Agustina, L. (2018). Pengaruh EPS, CR, DER dan ROA terhadap Harga Saham Perusahaan Batubara yang Terdaftar di Bursa Efek Indonesia Periode 2013-2015. Skripsi Universitas Muhammadiyah Surakarta.

Block, F. E. (1995). A Study of the Price to Book Relationship. Financial Analysts Journal, 51(1), 63-73. doi:10.2469/faj.v51.n1.1860

Brigham, E. E., Houston, J. F. (2016). Essentials of Financial Management. 14 th Edition. Singapore: Cengage Learning.

Chan, L.K.C., Jegadeesh, N., Lakonishok, J. (1995). "Evaluating the Performance of Value Stocks versus Glamour Stocks: The Impact of Selection Bias.” Journal of Financial Economics, 38(3), 69-96.

Dalimunthe, H. (2015). Pengaruh PER, Tingkat Suku Bunga dan Tingkat Inflasi terhadap Harga Saham. Jurnal Akuntansi dan Bisnis, 1(2), 36-45.

Fahmi, I. (2015). Analisa Laporan Keuangan. Cetakan Kelima. Bandung: Alfabeta.

Ghozali, I. (2016). Aplikasi Analisis Multivariate dengan Program. 8ed. Semarang: Badan Penerbit Universitas Diponegoro. 
Halim, A. (2018). Analisis Investasi dan Aplikasinya. 2 ed. Jakarta: Salemba Empat.

Hartono, J. (2017). Teori Portofolio dan Analisis Investasi. 11 ed. Yogyakarta: BPFE.

Hing, G. T., Alamsyah, A. R., Pradiani, T. (2020). Variabel-variabel yang Mempengaruhi Harga Pasar Saham pada Perusahaan Tambang Batubara yang Terdaftar di Bursa Efek Indonesia. Jurnal Ekonomi Manajemen dan Bisnis.

Hery. (2015). Analisis Laporan Keuangan: Pendekatan Rasio Keuangan. Yogyakarta: CAPS (Center for Academic Publishing Service).

Jitmaneeroj, B. (2017). Does investor sentiment affect price-earnings ratios? Studies in Economics and Finance. 34(2), 183-193

Kasmir. (2014). Analisis Laporan Keuangan. 1ed. Jakarta: PT. Raja Grafindo Persada.

Khairani, I. (2016). Pengaruh Earning Per Share dan Dividend Per Share terhadap Harga Saham Perusahaan Pertambangan yang Terdaftar di Bursa Efek Indonesia (BEI) Tahun 20112013. Jurnal Manajemen dan Keuangan, 5(1), 566-572.

Khairudin and Wandita. (2017). Analisis Pengaruh Rasio Profitabilitas, Debt To Equity Ratio (DER) dan Price to Book Value (PBV) terhadap Harga Saham Perusahaan Pertambangan di Indonesia. Jurnal Akuntansi dan Manajemen. 8(1), 68-84.

Lestari, I. (2012). Pengaruh EPS, DPR, PER, dan PBV terhadap Harga Saham pada Sektor Pertambangan di Bursa Efek Indonesia. Skripsi. Fakultas Ekonomi Universitas Sriwijaya.

Mahfudz, M., Dwinurcahyo, R. (2016). Pengaruh Faktor-faktor Fundamental terhadap Harga Saham (Studi pada Perusahaan Pertambangan yang Terdaftar di Bursa Efek Indonesia tahun 2012-2014). Diponegoro Journal of Management, 5(3), 210-224.

Malhotra, N., Tandon, K. (2013). Determinants of Stock Prices: Empirical Evidence from NSE 100 Companies, IRACST- International Journal of Research in Management \& Technology (IJRMT), 3(3), 86-95.

Nurriqli, A., Sofyan, S. (2018). Pengaruh Faktor-Faktor Fundamental terhadap Harga Saham (Studi Pada Perusahaan Sub Sektor Pertambangan Batubara yang Terdaftar di Bursa Efek Indonesia Periode 2012-2015). Kindai, 14(1),1-11.

Prabu, M.S., Fadila, D., Ummasyroh. (2020). Pengaruh EPS, PER terhadap Harga Saham Subsektor Batubara Perusahaan yang Terdaftar di Bursa Efek Indonesia Periode 20152019. Ekonomia, 10(2), 37-45.

Samsul, M. (2015). Pasar Modal dan Analisis Portofolio . Edisi 2. Jakarta: Erlangga.

Sharma, S. (2011). Determinants of Equity Share Prices in India. Journal of Arts, Science \& Commerce, 2(4), 51-60. 
Silalahi, U. (2018). Metodologi Analisis Data dan Interpretasi Hasil untuk Penelitian Sosial Kuantitatif. Bandung: Refika Aditama.

Srinivasan, P. (2013). Determinants of Equity Share Prices in India: A Panel Data Approach. The Romanian Economic Journal, 46: 205-228. Available at: http://www.rejournal.eu/Portals/0/JE\%2046/Srinivasan.pdf

Sujarweni and Wiratna, V. (2017). Analisis Laporan Keuangan Teori, Aplikas dan Hasil Penelitian. Pustaka Baru Press: Yogyakarta.

Sukamulja, S. (2019). Analisis Laporan Keuangan sebagai Dasar Pengambilan Keputusan Investasi. Yogyakarta: Andi dengan BPFE.

Tandelilin, E. (2017). Pasar Modal (Manajemen Portofolio dan Investasi. Yogyakarta: PT. Kanisius.

Wira, D. (2011). Analisis Fundamental Saham. Indonesia: Exceed.

Zuliarni, S. (2012). Pengaruh Kinerja Keuangan terhadap Harga Saham pada Perusahaan Mining and Mining Service di Bursa Efek Indonesia (BEI). Jurnal Aplikasi Bisnis, 3 (1), 36-48.

Pratiwi, I. (2021, 10 Januari). Pemanfaatan Batu Bara untuk Dalam Negeri Terus Didorong. Republika, accessed from https://www.republika.co.id/berita/qmq3jz370/pemanfaatan-batu-bara-untuk-dalamnegeri-terus-didorong

Septyaningsih, I. (2020, 24 November). Tren Ekspor Batu Bara Indonesia Meningkat. Republika, accessed from https://republika.co.id/berita/qkaqa3457/tren-ekspor-batubara-indonesia- at 13 December 2020. 